\title{
REFORMATION OF THE STRUCTURE INTERNATIONAL HEALTH LAW IN ORDER TO IMPROVE THE TRANSBOUNDARY INFECTIOUS DISEASES MANAGEMENT ${ }^{\Omega}$
}

\author{
Aktieva Tri Tjitrawati \\ International Law Department, Law Faculty of Airlangga University \\ E-mail: evatjitrawati@yahoo.com
}

\begin{abstract}
The structure of international health law is currently composed under the philosofical basis of segregate and dichotomous international community. This structure affects the handling and management of TID, which is currently much harm the interests of developing countries as the emerging of multinational pharmaceutical companies. This study aimed to understand and analyse the existing system and structure of international health law (lex lata) to be used as a basis in an effort to design an ideal structure of international health law system.
\end{abstract}

Key words: international health, reformation, legal structure.

\begin{abstract}
Abstrak
Struktur hukum kesehatan yang ada saat ini didasarkan pada filosofi pemisahan dan saling berhadapan dari anggota-anggota masyarakat internasional Struktur demikian sangat mempengaruhi pengaturan dan pengelolaan penanganan TID yang banyak merugikan kepentingan Negara berkembang. Penelitian ini ditujukan untuk memahami dan menganalisis sistem dan struktur hukum kesehatan internasional yang ada (lexlata) untuk digunakan sebagai dasar dalam upaya menemukan rancangan struktur yang ideal sebagai bahan melakukan reformasi kesehatan internasional. Hasil penelitian menunjukkan bahwa diperlukan konsep-konsep hukum kesehatan yang reformis untuk menyeimbangkan kepentingan para stakeholder untuk mencapai hukum kesehatan internasional yang lebih adil.
\end{abstract}

Kata kunci: kesehatan internasional, reformasi, struktur hukum.

\section{Introduction}

The legal system of international health at the moment consists of public and private rules and institutions, in both national and international levels aimed to achieve a high quality of health to the world population. Being the main actors in the legal system are individual, private service providers in the health sector, the state and the World Health Organization (WHO). WHO as an international authority which had the most dominant functions and authority in regulating the system of international health law. The sys-

$\Omega \quad$ This article is a summary from the result of funded research through the UPT Airlangga University scheme in 2015.

1 Lawrence O. Gostin, "World Health Law: Toward a New Conception of Global Health Governance for the 21st Century", Yale Journal of Health Policy, Law, and Et- tem of international health law was not a standalone system, but a hooked and intersect with another various legal systems, such as international trade law, international environmental law and the law of human rights (HAM). ${ }^{1}$

Indonesia's decision not to carried out the virus sharing obligation in the extraordinary events (KLB) of the H5N1 virus in 2007 showed that system was not going well, ${ }^{2}$ as the result of an error in the operations of the international health law system due to the inaccuracy application of the law concepts which built the inter-

hics: Vol. 5: Numb. 1, March 2005, New Haven: Yale University, page 14 .

2 Endang R. Sedyaningsih, et.al., "Towards Mutual Trust, Transparency and Equity in Virus Sharing Mechanism: The Avian Influenza Case of Indonesia", Annals Academic of Medicine, Vol. 37, Numb. 6, June 2008, Singapore: Academy of Medicines Singapore, page 487. 
national health law structure at this time in order to solve the problem of cross-border spread diseseases (TID). ${ }^{3}$ Concepts of international health law nowadays still based on the Westphalian philosophy that led international law spawned a legal barriers based on boundaries and jurisdiction state. These concept would complicate the efforts to combat the infect diseases which are borderless. On the other hand, the higher role of the multinational pharmaceutical industry in the international health law system, require more power of the mechanisms controlling. This low control can led to a misuse of powers in the interest of the pharmaceutical industry with inherent basic character as an institution motivated to the profit (profit-oriented). ${ }^{4}$

\section{Research Problem}

a. What is the paradigmatic error in the relationship structure of the parties in the international health law system?

b. How does the impact of those conceptual error on the efficiency of the TID management?

\section{Research Method}

This research use legal research methods with a structural conceptual approach which the view of law as a counterweight of the in-terests (Roscoe Pound), and it is directed to the efforts of the law reform oriented. By this kind of approach, the law not only be regarded as normative products, but also should be seen as social interaction product, this carried out by the international community, in handled the TID. Conceptual approaches directed to assess the validity of the exisiting law (lex lata) for subsequent use as a means to find new concepts in order to draft the legal structure of a fairer international health.

For next was shortened as TID

Aktieva TriTjitrawati, "Masalah Keadilan Pelaksanaan Kewajiban Virus Sharing dalam Sistem IHR", Mimbar Hukum, Vol. 2, Numb. 1, February 2013, Yogyakarta: Universitas Gadjah Mada, page 53.

\section{Discussion}

The System and The Structure of International Health Law: lex lata

International health law system was currently based on the international relations philosophy which is dichotomied in a group and the interests of developed and developing countries, which is polarized in an imbalance opportunity to obtain the decent medical degree between the two groups. The dichotomous and paradoxal approach in the international health law structure often caused a range policy produced by WHO, as the authority which has dominant authorized in the international health legal system, both in setting the interests of the developed countries with the developing countries, and between the international health policy with national health policy of countries. ${ }^{5}$ As a result, the international health policies, particularly with regard to the management of TID still could not be used as a tools to prevent the spread of infectious diseases. ${ }^{6}$

Image 1. International Law Structure in Managed the TID

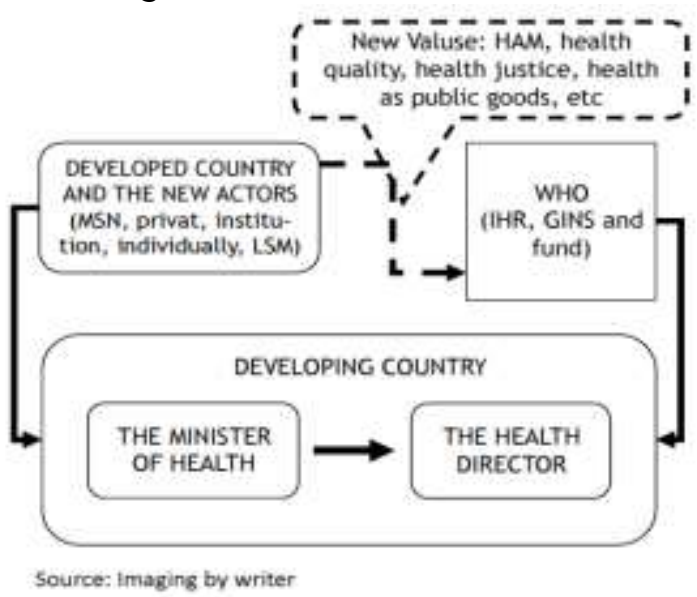

The handling of TID in international health systems are a part of the germ governance which are an infectious diseases governance handled by the public, both in the national and international levels. Governance refers to the society's structure, both nationally and internationally,

5 Obijiofor Aginam, “International law and communicable diseases", Bulletin of the World Health Organization, Vol. 80, No.12, August 2008, Jenewa: WHO, page 4.

6 Lance Sakre, et.al., "Globalization and Infectious Diseases: A Review of he Linkages", Circulation in Social, Economic and Behavioural Research, UNICEF, TDR/STR/ SEB/ST.04.2, Jenewa: UNICEF, page 9. 
facing the threat of microbiological organisms which are increasing and globalize as well remembering that the threat of the disease is unlimited by the territorial state jurisdiction. The multifacet side of handling this infectious disease caused the interrelated and ramifications of various rules and legal institutions. ${ }^{7}$

Historically, the handling of TID was done in two ways, there were the governance of the disease within the state territory and the governance of states, where both of the strategies are being developed in order to conduct a war against the infectious diseases, thats way in the there are two governance strategies of management the infectious disease, which are horizontal and vertical governance infectious diseases. ${ }^{8}$ Horizontal governance puts the state as the dominant actor in the handled and preventioned of disease transmission which are focused on trade handling and movement of people between countries. This approach assumes that the threat of infectious diseases is an external (exogenous threat) to the interests and national power that can only be solved through the international cooperation. ${ }^{9}$

The vertically handling procedure consider the infectious diseases as a threat from inside, so that more emphasis in handling the threat of the disease through the establishment and development of national health systems. The developing concepts in vertical disease management strategy emphasizes the rights of the public health and to reduce the dominance of the state over the handling of infectious diseases. ${ }^{10}$ The reduction of the country's dominance allows a new actor in international law, such as non-governmental organizations and multinational pharmaceutical companies, participated in

Obijofor Aginam, loc.cit.

Fiedler, David P., “Influenza Virus Samples, International Law, and Global Health Diplomacy", Emerging Infectious Diseases, Vol.14, No.1, January Edition of 2008, page. 3.

9 David P. Fiedler, "Germs, governance, and global public health in the wake of SARS", The Journal of Clinical Investigation, Vol. 113, No. 6, March 2004, page 799.

10 For further read: Monica Desai, "Critical interactions between Global Fund-supported programmes and health systems: a case study in Indonesia", in Health Policy and Planning, , Vol. 44, No. 25, September 2010, Oxford: Oxford Journal, page 143-147. the treatment of infectious diseases, especially from the political and functional aspect. ${ }^{11}$

After the Second World War, both horizontal and vertical approaches tend to be used together (hybrid approach), even so, the developed countries are tend to use a vertical approach, while developing countries tend to use a horizontal approach. The use of horizontal approach in practical bring the legal provisions in the prevention of a disease that is "international", not global. That "international" provisions put countries and international organizations as the main actor, where it is also attached the attributes of the countries soveregnty. While the vertical approach reach more actors in the prevention of infectious diseases, because it includes a non-state actors such as non-governmental organizations (NGOs) and the multinational pharmaceutical companies. The globally vertical approach is more appropriate with the current conditions that the countries will not be able to face the threat of the infectious disease without the involvement of that non-state actors. ${ }^{12}$ Some non-state actors even had more power in determining the policy of domestic health in a country rather than the concerned country. ${ }^{13}$

\section{The Role Reduction of WHO in Implementation The International Health System}

WHO nowadays is still the most dominant actor in the administration of international health system, but WHO is now diminishing its role compared to other agencies working in the same field, whether in the public or private sector, such as the World Bank, the pharmaceutical multinational company, even private institutions such as the Bill Gates and Melinda Foundation. ${ }^{14}$ The Bill Gates foundation had more im-

11 Stacey Knobler, 2006, "A World in Motion: The Global Movement of People, Products, Pathogens, and Power", Makalah dalam Lokakarya The Impact Of Globalization On Infectious Disease Emergence And Control:Exploring the Consequences and Opportunities, National Academy Forum on Microbial Threats, Board on Global Health Institute of Medicine of NAP, Washington, D.C., page 2148.

12 Fiedler, 2008, loc.cit.

13 Sara E. Davies, 2010, Global Politics of Health, Cambridge: Polity Press, page 32.

14 David McCoy, et.al., "Global health funding: how much, where it comes from and where it goes", dalam Health 
portant role in handling the international health problems, even the funds from the foundation for health programs in many countries, especially in poor countries, had more exceeding funds rather than fund that provided by WHO. The amount of the fund and the absence of a convoluted bureaucracy as in large international organizations such as WHO, causing more efficient handling of health problems. Since 2000, the Gates Foundation had been conducted many communicable disease prevention programs such as HIV/AIDS and malaria with millions of dollars in fund, including many efforts to prevent health issues and disease prevention funded by Bill Gates personally before the establishment of those foundation. ${ }^{15}$ In addition of the foundations and the individuals philanthropic, the efforts of health management also carried out by non-govern-mental organizations (NGOs). CDC (Center for Disease Control and Prevention), for example, had 60 years of coordinate and manage the resources and the expertise to handled the iss-ue of global health and disease, such as HIV/AIDS, malaria, and the health care of refugees and disasters, in addition to developing health system strengthening programs. ${ }^{16}$

The existence of other actors outside the WHO and this country, on the one hand can help accelerate the achievement of the purposes of international health systems more effectively, but on the other hand it could be a potential nuisance for the implementation of national health programs of the recipient countries. According to Venkatapuram, that disorder occur due to several factors: first, if the purposes mission of the program are carried out by these actors were different with the government programs; second, if the private donors are more likely to provide assistance to NGOs rather than to WHO it will threaten the implementation of WHO's health programs and the local governments; and third, if the funds managed by such

Policy and Planning, no. 24, July 2009, Oxford: Oxford University Press, page 407-417

$15 \mathrm{http}: / /$ www.gatesfoundation.org/Who-WeAre/General-Information/, accessed on February 25, 2015.

16 http://www.cdc.gov/globalhealth/who/index.htm, accessed on February 25, 2015. actors is obtained from the pharmaceutical companies are loaded with commercial interests, that programs could be compromised by the interests of the companies concerned. ${ }^{17}$ This is showed that even other actors outside the country and the WTO occupies the more important position, but the control of health program should remain in the hands of governments state, because they were the one who understand best about the problems and the ways of handling health issues in its region.

The Effect of Multinational Pharmaceutical Company in The International Health Law System

A Multinasional Companies (MNC) are the new actor of the international legal system who asserted its position. Even until nowadays, the MNC has not been considered as an international law subject which has a formal role in the established of law and the international policy, but with the economic's power, many MNCs have more power rather than the micro and the poor countries in influencing both of it. It is similar with the MNC in the pharmaceutical field.

The strength of the capital and financial owned by MNC pharmaceutical allows it affects the implementation of the international health systems, include through the lobbying against local government officials. The entrance of the me-icine's trade in the TRIPS patent protection mechanisms materialized after the MNC pharmaceutical was succesfully persuade the US delegates trying their best effort to enter the medicine patent protection in TRIPS. This success confirms and protects the MNC pharmaceutical strength in controlling the trade in drugs, especially the drugs is the merchandise that require capitalization in research and development (R\&D) which is very expensive with a low success rate, which can only be done by a large companies. ${ }^{18}$

17 Sidhar Venkatapuram, et.al., "Ethical tensions in dealing with noncommunicable diseases globally",Bulletin of the World Health Organization, Vol. 90, No. 3, March 2012, Jenewa: WHO, page 157-244.

18 Oxfam, "Oxfam Analysis of US Proposals for IP and Pharmaceutical Pricing Provisions in Trans-Pacific Partnership Agreement Negotiations", available on website 
The amount of strength and the dominant position also allows the MNC pharmaceutical com-anies determines the prices of the drug. With the reason of the R\&D costs, the MNC pharmaceutical ask the strong protection patent for drugs produced, so there is an incentive way to develop and produce drugs which are newer and more effective, even if the drug prices become more expensive. The problems are, the protection patent and the high prices of drugs make the poor people in developing countries hard to gain the access to the drugs they need. Moreover, the MNC pharmaeutical companies generally come from developed countries where most of the people have no diseased compared with communities in developing countries, so its not wonder if most of the produced drugs are the drugs which related to diseases caused by the lifestyle, not a disease caused by infectious diseases such as tuberculosis, diarrhea and another tropical diseases. ${ }^{19}$

\section{Global Politics of The International Health Law in Combating The TID}

An understanding of the international health law politics is an important factor to apply new concepts of the international health legal structure, given through the political process of negotiations it is determined by the rules and international health policy. The maintanance of the spread disease should be understood as a part of the global biosecurity ${ }^{20}$ which requires the cooperation of all stakeholders to deal with. The stakeholders, at the range of the local, the national and the global, should be involved and active in the formulation of policies which are able to prevent the outbreak, developing the early warning systems, develop the strategies and emergency responses, and to prepare the effective recovery efforts immediately after the crisis. The awareness of the importance of glo-

www.citizen.org/documents/Oxfam-Paper-on-theTPPA-Leaked-IP-Chapter.pdf, accesses on January 7, 2015.

19 Jesse B. Bump, et,al., "Diarrhoeal diseases and the global health agenda: measuring and changing priority", Health Policy and Planning, Vol. 28, No. 8, November 2012,Oxford: Oxford University Press, page 799-808.

20 Peter Katona dan W. Michael Scheld, 2010, "Emerging and Reemerging Infectious Diseases", Peter Katona, John bal cooperation once realized by composing and formulate the appropriate strategies to deal with the issue of TID. ${ }^{21}$

Besides to the association in securing international trade, global cooperation between countries also ensure the protection of human rights especially in relation to the right to enjoy good health standards. It is expressed directly in the preamble of the WHO Constitution which states: "The enjoyment of the highest attainable standard of health is one of the fundamental rights of every human being without distinction of race, religion, political belief, economic or social condition". The statement in the preamble closely linking global public health issues as part of the human rights protected by international law, which next to be the basis for global cooperation in controlling the spread of TID

\section{Structural Reformation of The International} Law to Improve The Immunity of TID Threat

Strategies to face the problems of TIDs have been formulated for a long time ago, but these strategies would not work without the ground rules that bind the countries and the authorized institutions indeed to uphold the commitment to apply national rules to directing the citizens in preventing and facing the threat of TIDs spread. The International regulations that directly regulate countermeasures of TID is the International Sanitary Conventions (ISCs), which was replaced by the International Health Regulations (IHR) in 1951 which further improved in the next few IHR provisions. IHR 2007 was guide all WHO states member nowadays. The provisions of are essentially focused to the efforts to prepare a protection against the threat of TIDs through the establishment of an information network and the international security, which allows the countries to provide information in each others about the dangers of TID, so

P. Sulivan, dan Michael D Intriligator (ed), Global Biosecurity Threat and Response, New York: Routledge, page 5.

21 Philippe Calain, "Exploring the international arena of global public health surveillance", Health Policy and Planning, Vol. 22, No. 1, September 2006, Oxford: Oxford University Press, page 2-12. 
as to make a preparations and take the right precautions.

Health are closely related to the political, social and economic aspects. Injustice in the distribution of health, therefore, is also associated with the inequities in the distribution of global prosperity. Its the fact that most of the poor countries that had low health degree was a former colony, while countries with a high degree of health are mostly former colonial countries. Mistakes in managing the problem of global poverty, in view of Pogge, is a moral crime committed by the developed countries that caused the perpetuation of poverty in developing countries. $^{22}$

\section{Global politics of international health law to eradication TID \\ Comprehension of international health} law politic is the important factor to propose new concepts of international health law structure, remembering by political process to this negotiation will be determined international health rules and policies. Handling the spread of disease must be understood as part of global biosecurity ${ }^{23}$ that need cooperation from all stakeholder to face it. All stakeholder, in local level, national and global, should be involved and active in making policies to prevent disease, developing warning system, making the right strategy and planning to understand the emergency warning, and prepare effective recovery effort after crisis. Awareness of importance global cooperation can be realized by making and formulate the right strategy to face TID problem. ${ }^{24}$

Beside to securing international trade, global cooperation among countries also to ensure protection of human rights especially rig-ht to take benefit of good health standard. This is directly shown in preambul of the WHO Constitution: "enjoyment of the highest attainable standard of health is one of the fundamental

22 Ted Schrecker, “Interrogating scarcity: how to think about 'resource-scarce settings', dalam Health Policy and Planning, Vol. 28, No. 4, Agustus 2013, Oxford: Oxford University Press, page 400-409.

23 Jesse B. Bump, et,al., "Diarrhoeal diseases and the global health agenda: measuring and changing priority", rights of every human being without distinction of race, religion, political belief, economic or social condition". That statement related with global public health problem as part of human right which is protected by international law, for the next become the basis of global cooperation to con-trolling the spread of TID.

\section{Reformation of International Law Structure to Increase Immunity of TID Threats}

Strategy to face TIDs problem can be defined since long time, but this strategies won't running without binding regulations among countries and institutions to commit applied national regulations that guide the society to prevent and face TIDs threats. International regulations which directly organized TID is International Sanitary Conventions (ISCS) and then replaced by International Health Regulations (IHR) in 1951 and after that repaired by the next IHR provisions. IHR 2007 become guidance for all countries WHO members right now. The point of that provisions is effort to prepare protection of TIDs threats by creating information network and international controlling, that possibility all countries can give information each others about TID danger, so the country can prepare and take the right action to prevent.

Health has related with political, social and economic aspects. Injustice of health distribution, also related with injustice of global welfare distribution. The fact that most of poor country that have low health level is former colony, and the country that have high health level is the former colonies. Failure in handling global poverty, in Pogge's opinion, is moral crime that did by developed country that causes poverty in developing country. ${ }^{25}$

System of economic aid and loans to po-or countries is done by shifting the depletion of natural resources through corrupt rulers and oppressive, so that economic aid and programs

Health Policy and Planning, Vol. 28, No. 8, November 2012,Oxford: Oxford University Press, page 799-808.

24 Peter Katona and W. Michael Scheld, op.cit.

25 Ted Schrecker, "Interrogating scarcity: how to think about 'resourcescarce settings', in Health Policy and Planning, Vol. 28, No. 4, August 2013, Oxford: Oxford University Press, page. 400-409. 
undertaken not bring benefits to the development community. ${ }^{26}$ Models such aid also led to the grouping of countries into "donor" and "recipient", where donor countries are in a position higher than the state-assisted, so there's inequality in it. ${ }^{27}$ Health assistance practices with a model like this causes low responsibility of poor countries recipient of the handling of health problems of their own community, because they regard it as a project of the developed countries that imposed its implementation in their country. ${ }^{28}$

Reformation of international health law should be placed in paradigm that global health problems are problems of humanity that transcend the boundaries of state jurisdiction, where all countries have obligation to handle it. All countries, both developed or developing, should make contribution of health problems, remember that all humans have to face the same diseases threats. ${ }^{29}$ So, organizing global health should be seen of cooperation among countries to achieve the goal which is increasing global health level, reducing injustice global health, and achieve sustainable global heal-th. ${ }^{30}$

By this concepts, so financial and technical helps that given from developed countries to countries that have low health level must be seen as effort to achieve the goal. Especially to face financial problem of developing countries to face TID, so budget for prevention diseases program in global, regoinal and international should be directed to support national prevention program which held by own develo-ping countries. Developing countries should develop mechanism to prevent the spread of TID nationally which is equipped with a monitoring mechanism and prevention of the outbreak by the Government, in accordance with the provisions of international health law on the prevention of communicable diseases set out in IHR 2007. ${ }^{31}$ This is critical points may be happen among in-

26 Steven J Hoffman, 2010, "The evolution, etiology and eventualities of the global health security regime", in Health Policy and Planning, Vol.25, August Edition 2013,Oxford: Oxford University Press, page 510-522

27 David McCoy, loc.cit.

28 Gillian Brock, 2012, "Global Health and Responsibility", in Patti Tamara and Christine Straehle (ed), op.cit., page 106. terest of developed countries, developing countries, and WHO. Developed countries as donor have strong position to push their interest in formulated IHR and GINS (Global Influenza Surveillance Network) in WHO forum, that may be different with interest of developing countries, like when Indonesia face out-break virus H5N1 in 2007.

\section{Closing \\ Conclusion}

Based on the analysis conducted, it can be concluded that: first, paradigm failure in structure of relatio-nship sides in international health law system is disparities and inequality act-ors play an important role in the system, and countries still strong to hold their sovereignty when must face infection diseases threats which is crossborder; second, there'r new actors from abroad in health law system causes need for a new approach in coordinating these actors so that disease management can be imple-mented efficiently and structured.

\section{Suggestions}

According the above discussion and conclusion it can be suggested in the future in an effort of reformation in the structure of international health law are: first, new concepts are needed to correct the error paradigmatic structure of relations in the system of international health law given the growing role of new actors outside the country and the stronger the urge to associate health protection with the protection of human rights. Concepts that can be submitted are: affirmation of the position of health protection for developing countries, the readiness of countries in dealing with disease out-breaks, strengthening the link between health and human rights protection and sustainability, and to formulate more clearly what definition of health as public goods. Second, giving comprehension

29 Oleg Chestnov,et.al., "Towards the world we want", in Bull World Health Organ, Vol. 92, Number 9, September 2014, Jenewa: WHO, page 623.

30 Iris Borowya, "Sustainable health: the need for new developmental models", in Bull World Health Organ; Vol. 92, No. 10, October 2014, Jenewa: WHO, page 699.

31 Philippe Calain, "From the field side of the binoculars: a different view on global public health surveillance", Health Policy and Planning, Vol. 22, No. 1, September 2006, Oxford: Oxford University Press, page 13-20. 
to all countries that face TIDs is borderless, sovereignty can no longer be interpreted in absolute terms.

\section{Bibliography}

Aginam, Obijiofor. "International law and communicable diseases". Bulletin of the World Health Organization, Vol. 80 No. 12. August 2008. Jenewa: WHO;

Borowya, Iris. "Sustainable health: the need for new developmental models". Bull World Health Organ, Vol. 92. No. 10. October 2014. Jenewa: WHO;

Bump, Jesse B., et,al., "Diarrhoeal diseases and the global health agenda: measuring and changing priority". Health Policy and Planning. Vol. 28. No. 8. November 2012. Oxford: Oxford University Press;

Calain, Philippe. "Exploring the international arena of global public health surveillance". Health Policy and Planning. Vol. 22. No. 1. September 2006. Oxford: Oxford University Press;

Calain, Philippe."From the field side of the binoculars: a different view on global public health surveillance". Health Policy and Planning. Vol. 22. No. 1. September 2006. Oxford: Oxford University Press;

Chestnov, Oleg., et.al. "Towards the world we want". in Bull World Health Organ, Volume 92. No 9 Sept 2014, Jenewa: WHO;

Davies, Sara E. 2010. “Global Politics of Health", Cambridge: Polity Press;

Desai, Monica. "Critical interactions between Global Fund-supported programmes and health systems: a case study in Indonesia". in Health Policy and Planning. Vol. 44. No. 25. Sept 2010. Oxford: Oxford University;

Fiedler, David P. "Germs, governance, and global public health in the wake of SARS". The Journal of Clinical Investigation. Vol. 113. No. 6. March 2004;

-..--.-, "Influenza Virus Samples, International Law, and Global Health Diplomacy". Emerging Infectious Diseases. Vol. 14. No. 1. January 2008;

Gostin, Lawrence 0. "World Health Law: Toward a New Conception of Global Health Governance for the 21st Century". Yale Journal of Health Policy, Law, and Ethics: Vol. 5 No. 1. Maret 2005. New Haven: Yale University;

Hoffman, Steven J. 2010. "The evolution, etiology and eventualities of the global health security regime". Health Policy and Planning. Vol. 25. August 2013. Oxford: Oxford University Press;

Katona, Peter., John P. Sulivan and Michael D Intriligator (ed). 2010. "Global Biosecu-rity Threat and Response". New York: Routledge;

Knobler, Stacey. 2006. "A World in Motion: The Global Movement of People, Products, Pathogens, and Power". Makalah dalam Lokakarya The Impact Of Globalization On Infectious Disease Emergence And Control: Exploring the Consequences and Opportunities, National Academy Forum on Microbial Threats, Board on Global Health Institute of Medicine of NAP. Washington, D.C.

McCoy, David., et.al. "Global health funding: how much, where it comes from and where it goes". dalam Health Policy and Planning. no. 24. July 2009. Oxford: Oxford University Press;

Oxfam, "Oxfam Analysis of US Proposals for IP and Pharmaceutical Pricing Provisions in Trans-Pacific Partnership Agreement Negotiations". in www.citizen.org/documents/ Oxfam-Paper-on-the-TPPA-Leaked -IP-Chapter.pdf. accessed on January, $7^{\text {th }}$ 2015;

Sakre, Lance., et.al. "Globalization and Infectious Diseases: A Review of he Link-ages". Sirkulasi dalam Social. Economic and Behavioural Research, UNICEF. TDR/STR/ SEB/ST.04.2. Jenewa: UNICEF;

Schrecker, Ted. "Interrogating scarcity: how to think about 'resource-scarce settings' . dalam Health Policy and Planning. Vol. 28. No. 4. August 2013. Oxford: Oxford University Press;

Sedyaningsih,Endang R.et.al. "Towards Mutual Trust, Transparency and Equity in Virus Sharing Mechanism: The Avian Influenza Case of Indonesia". Annals Academic of Medicine. Vol. 37. No. 6. June 2008. Singapore: Academy of Medicines Singapore;

Tjitrawati, Aktieva Tri. "Masalah Keadilan Pelaksanaan Kewajiban Virus Sharing dalam Sistem IHR”. Mimbar Hukum. Vol. 2, No.1. February 2013. Yogyakarta: Universitas Gadjah Mada;

Venkatapuram, Sidhar. et.al. "Ethical tensions in dealing with noncommunicable diseases globally". Bulletin of the World Health Organization. Vol. 90. No. 3. March 2012. Jenewa: WHO. 